\title{
INFLUENCE OF LEAF AREA REDUCTION ON CLONAL PRODUCTION OF EUCALYPTUS SEEDLINGS
}

\author{
Reynaldo Campos Santana ${ }^{1}$, Tiago Reis Dutra ${ }^{2}$, José Pereira Carvalho Neto², Gilciano Saraiva Nogueira ${ }^{3}$, \\ Paulo Henrique Grazziotti ${ }^{4}$, Nairam Félix de Barros Filho ${ }^{5}$
}

(received: September 10, 2008; accepted: April 30, 2010)

\begin{abstract}
Clonal production of eucalyptus seedlings has made considerable progress in recent years. Significant developments have taken place in irrigation and fertilization systems as well as in management of clonal miniorchards. However, the proportion of leaf area in stem minicuttings remains almost the same as that used in macrocutting systems. This work aimed to evaluate the effect of leaf area reduction on seedling production of eight eucalyptus clones. The experiment was conducted over a period of 105 days using a randomized block design and three replicates in an $8 \times 4$ factorial arrangement, with eight clones and four leaf reduction levels (0\%, 25\%, 50\% and 75\%). Variables evaluated included height, root collar diameter, shoot and root dry matter and relationships between these variables. Experimental results demonstrated that clones behaved differently as to leaf reduction and that the $0 \%$ reduction level can be adopted in most clones being evaluated.
\end{abstract}

Key words: Minicutting, leaf area, clonal silviculture.

\section{INFLUÊNCIA DA REDUÇÃo DA ÁREA FOLIAR NA PRODUÇÃo DE MUDAS CLONAIS DE EUCALIPTO}

RESUMO: A produção clonal de mudas de eucalipto evoluiu muito nos últimos anos. Grandes avanços foram obtidos nos sistemas de irrigação, de fertilização e no manejo do minijardim clonal. Entretanto, a proporção de área foliar das miniestacas continua praticamente a mesma que se utilizava no sistema de macroestaquia. Objetivou-se, no presente estudo, avaliar o efeito da redução da área foliar na produção de mudas de oito clones de eucalipto. O experimento foi conduzido por 105 dias no esquema fatorial $8 \times 4$, com oito clones, quatro níveis de redução foliar $(0,25,50$ e $75 \%)$ em delineamento em blocos casualizados e três repetições. Avaliouse a altura, o diâmetro do coleto, a massa da parte aérea e de raiz e relações entre estas variáveis. Os resultados desse experimento demonstram que os clones comportaram-se de forma distinta em relação à redução foliar e que o nível de $0 \%$ de redução foliar pode ser adotado para a maioria dos clones avaliados.

Palavras-chave: Miniestaquia, área foliar, silvicultura clonal.

\section{INTRODUCTION}

Successful development of high-productivity forest stands is largely dependent on the quality standard of the relevant seedlings (GOMES et al. 2002). Today, mass multiplication of eucalyptus relies primarily on rooting of stem minicuttings derived from superior genetic materials, propagated by stem mini- and microcuttings (XAVIER et al. 2009). According to Titon et al. (2003), the technique known as minicutting has helped achieve considerable gains in ministump productivity, improving uniformity and rooting percentage when strict control practices are adopted in the nursery.
Several factors influence plant propagation by stem cuttings, including presence of buds and/or leaves and season of harvest (HARTMANN et al. 2002), nutritional condition (BELLAMINE et al. 1998, SCHAWAMBACH et al. 2005), species type, presence of rooting inducers and inhibitors (FOGAÇA \& FETT-NETO 2005, WENDLING \& XAVIER 2005) and variations in growth factors, water, light, nutrients and relevant interactions (VALLE \& CALDEIRA 1978).

Constituent elements of the substratum also influence the rooting process (HIGASHI et al. 2000). Minicutting juvenility is another potentially influencing element, with older minicuttings tending to have larger

\footnotetext{
${ }^{1}$ Forest Engineer, Dr. Professor of Soils and Plant Nutrition - Departamento de Engenharia Florestal - Universidade Federal dos Vales do Jequinhonha e Mucuri - Rua da Glória, 187, Centro - 39.100-000 - Diamantina, MG, Brasil - silviculturaufvjm@yahoo.com.br ${ }^{2}$ Forest Engineer, M.Sc. candidate in Plant Production - Programa de Pós-Graduação em Produção Vegetal - Universidade Federal dos Vales do Jequinhonha e Mucuri - Rua da Glória, 187, Centro - 39.100-000 - Diamantina, MG, Brasil - tiagoreisdutra@gmail.com, joseeflorestal@yahoo.com.br

${ }^{3}$ Forest Engineer, Dr. Professor of Dendrometry and Forest Inventory - Departamento de Engenharia Florestal - Universidade Federal dos Vales do Jequinhonha e Mucuri - Rua da Glória, 187, Centro - 39.100-000 - Diamantina, MG, Brasil - nogueirags@ yahoo.com.br ${ }^{4}$ Agronomist, Dr. Professor of Soil Microbiology and Biochemistry - Departamento de Engenharia Florestal - Universidade Federal dos Vales do Jequinhonha e Mucuri - Rua da Glória, 187, Centro - 39.100-000 - Diamantina, MG, Brasil - grazziot@yahoo.com.br ${ }^{5}$ Forest Engineer, M.Sc. in Forest Engineering - Plantar Reflorestamento S/A - nairamf@yahoo.com.br
} 
leaves than young ones. A larger proportion of leaf area can reduce humidity in the substratum by obstructing the passage of irrigation and due to intenser transpiration.

Minicutting is a silvicultural practice commonly used in clonal seedling nurseries, where vegetative propagules are about 4 to $8 \mathrm{~cm}$ in size and have at least two pairs of leaves (ALFENAS et al. 2004). In some species, the presence of leaves or a portion of them is essential for the rooting of stem minicuttings, since the photosynthesis process lead to carbohydrate storage which in turn favors root growth (HARTMANN et al. 2002).

Water loss is a major cause of minicutting death prior to root formation, since for cell division to occur it is necessary that cells of the minicutting tissue be turgid (NOBERTO et al. 2001). In order to prevent water loss by transpiration, Alfenas et al. (2004) recommend reducing the leaf blade of minicuttings by a third, while Xavier et al. (2009) argue that a 50\% reduction is the most common proportion in clonal production of eucalyptus seedlings in Brazil. The reason for leaf reduction is to avoid the 'umbrella' effect that potentially impairs irrigation efficiency, and to avoid excess transpiration and bending of minicuttings.

The leaf reduction technique is almost the same as that used in the eighties and nineties in seedling production by stem macrocuttings, only the vegetative propagule of minicuttings is comparatively smaller and younger than in macrocuttings, noting that irrigation systems have made considerable progress in recent years. With the above in mind, the aim of this study is to evaluate the effect of leaf area reduction on growth and quality of clonal eucalyptus seedlings.

\section{MATERIAL AND METHODS}

The experiment was conducted between April and June 2007 in the clonal nursery of Plantar Reflorestamentos S.A., a company located in Curvelo-MG. An 8 x 4 factorial arrangement was used to study the effect of eight genetic materials $-C 1, C 2, C 3, C 4, C 5, C 6, C 7, C 8$ which are commercial clones of the above company consisting of hybrid Eucalyptus urophylla S.T. Blake - and four leaf reduction levels $(0 \%, 25 \%, 50 \%$ and $75 \%)$, using a randomized block design and three replicates. The experimental unit consisted of 30 central plants in 190cavity trays to a total of 2,880 seedlings. The remaining seedlings were regarded as outer border seedlings and given the same treatment.

Leaf area reductions $(R F)$ were performed by transversely cutting leaves of apical minicuttings 6 to $8 \mathrm{~cm}$ high and containing one pair of fully formed leaves. $R F$ was performed by four trained nursery employees following the recommended proportions. The minicuttings were then placed at a depth of 1 to $2 \mathrm{~cm}$ in the center of a plastic seedling tube with a capacity of $55 \mathrm{~cm}^{3}$, containing a substratum composed of $40 \%$ medium vermiculite, $40 \%$ scorched rice husk and $20 \%$ coconut husk fiber. Base fertilization of the substratum consisted of $2.4 \mathrm{~kg} \mathrm{per} \mathrm{m}^{3}$ of slow release fertilizer $(13 \% \mathrm{~N}, 6 \%$ $\mathrm{P}_{2} \mathrm{O}_{5}, 16 \% \mathrm{~K}_{2} \mathrm{O}, 1.4 \% \mathrm{Mg}, 10 \% \mathrm{~S}, 0.26 \% \mathrm{Fe}, 0.02 \% \mathrm{~B}, 0.05 \%$ $\mathrm{Cu}, 0.06 \% \mathrm{Mn}$ and $0.015 \% \mathrm{Mo}$ ).

Plants were left in a greenhouse for 15 days, being irrigated by nebulization so as to maintain relative humidity above $70 \%$. They were then transferred to a shade house and left for another 15 days, each seedling receiving $4 \mathrm{ml}$ of fertirrigation a day $(50 \%$ in the morning and $50 \%$ in the afternoon), after which time they were transferred to the outdoor growth area. From then on, each seedling received $6 \mathrm{ml}$ of fertirrigation a day until they were 90 days old. In all growth phases, the experiment was conducted concurrently with the company's operationally produced seedlings.

The fertirrigation solution consisted of: $5.5 \mathrm{~kg}$ $\mathrm{Ca}\left(\mathrm{NO}_{3}\right)_{2}, 1.5 \mathrm{~kg} \mathrm{MgSO}_{4}, 2.63 \mathrm{~kg} \mathrm{KCl}, 0.9 \mathrm{~kg} \mathrm{NH}_{4} \mathrm{H}_{2} \mathrm{PO}_{4}$, $2.0 \mathrm{~kg} \mathrm{NH}_{4} \mathrm{SO}_{4}, 0.035 \mathrm{~kg} \mathrm{H}_{3} \mathrm{BO}_{3}, 0.004 \mathrm{~kg} \mathrm{CuSO}_{4}, 0.015 \mathrm{~kg}$ $\mathrm{ZnSO}_{4}, 0.017 \mathrm{~kg} \mathrm{MnSO}_{4}, 0.02 \mathrm{~kg}$ of ferrilene, $2.5 \mathrm{~kg}$ of simple superphosphate to $1,000 \mathrm{~L}$ of water.

After 105 days, measurements were taken of the shoot part $(H ; \mathrm{cm})$, root collar diameter $(D C ; \mathrm{mm})$, survival rate (\% of live plants), shoot dry matter ( $P A ; \mathrm{g} / \mathrm{plant})$, root dry matter $(R ; \mathrm{g} /$ plant $)$ and total dry matter $(M S T=P A+R ; \mathrm{g} /$ plant). For dry matter determination, all 30 plants in each experimental unit had the shoot parts separated from the root parts. The root part of each seedling was washed under running water, then dried in a forced air oven at around $65^{\circ} \mathrm{C}$ to constant weight. Measurement of shoot height was taken from the tube surface to the apical tip, and measurement of root collar diameter was taken level with the tube. These parameters were converted into seedling quality indices, as suggested by Gomes et al. (2002): H/DC, H/PA, PA/R and Dickson Quality Index (IQD), as given by:

$$
I Q D=M S T(\mathrm{~g}) /[H(\mathrm{~cm}) / D C(\mathrm{~mm})+P A(\mathrm{~g}) / R(\mathrm{~g})]
$$

Where data met normality assumptions, they were submitted to analysis of variance, then regression equations were developed, linear and quadratic, for growth characteristics assessed as dependent variables of leaf reduction levels. Equations were considered valid if they showed a 5\% significance level for the highest order 
coefficient (ÁLVARES \& ÁLVARES 2003). Results were compared using the Tukey test at the 5\% probability level. Where data did not meet normality assumptions, descriptive statistics was used. All statistical analyses were performed using Statistica 7.0 software.

\section{RESULTS AND DISCUSSION}

Good experimental precision was observed, validated by low coefficients of variation for variables $H$, $D C, H / D C$ and $H / P A$ (Table 1). Higher coefficients of variation were observed for variables $P A / R$ and $R$. Despite high, similar values were observed for root dry matter by Gomes et al. (2002) and by Titon et al. (2006).

Table 1 shows that the effect of leaf reduction for $H / D C$ and for $R$ was nonsignificant, in other words, different leaf reduction levels did not affect the development of these variables and so, on the basis of these variables, any of the leaf reduction levels applied here can be used for seedling production.

$P A / R$ and height results showed a significant effect isolatedly for clone and for leaf reduction. Despite the significant effect for $P A / R$, there was no fit of regression equations, linear or quadratic, presenting coefficients with a significance level below $5 \%$ (Figure 1). The quadratic fit for height provided a very low $\mathrm{R}^{2}$ value. Despite the quadratic fit, in practical terms any leaf reduction level can be adopted since observed results lie within the 15 to 35 $\mathrm{cm}$ range defined as being suitable for the planting of $E$. uroplylla seedlings (CARNEIRO 1995).

Variables $P A, D C$ and $H / P A$ showed a significant effect of interaction (Table 1). Clonal response to leaf reduction was found to vary differently depending on the variable being analyzed (Table 2). Different responses of the same genetic material depending on the variable being analyzed were also observed by Gomes et al. (2002) and Santana et al. (2007).

Table 1 - Analysis of variance of assessed parameters in seedlings of eight eucalyptus clones 105 days old.

Tabela 1 - Análise de variância dos parâmetros avaliados nas mudas de oito clones de eucalipto aos 105 dias de idade.

\begin{tabular}{lccccccccc}
\hline \multirow{2}{*}{ Source } & \multirow{2}{*}{ DF } & \multicolumn{7}{c}{ Mean square } \\
\cline { 3 - 9 } & & $\mathrm{H}$ & $\mathrm{R}$ & $\mathrm{H} / \mathrm{DC}$ & $\mathrm{Ln}$ PA/R & $\mathrm{DC}$ & $\mathrm{PA}$ & $\mathrm{H} / \mathrm{PA}$ & IQD \\
\hline Block & 2 & $2.36^{\text {n.s }}$ & $0.04400^{\text {n.s }}$ & $1.394^{* *}$ & $0.045933^{\text {n.s }}$ & $0.0879^{* *}$ & $0.00624^{\text {n.s }}$ & $17.72^{*}$ & $0.001642^{*}$ \\
Clone (C) & 7 & $37.08^{* * *}$ & $0.25880^{* *}$ & $2.673^{* *}$ & $0.267156^{* *}$ & $0.1700^{* *}$ & $0.07052^{* *}$ & $88.50^{* *}$ & $0.004692^{* * *}$ \\
Reduction (RF) & 3 & $40.47^{* *}$ & $0.04871^{\text {n.s }}$ & $0.542^{\text {n.s }}$ & $0.250000^{*}$ & $0.2862^{* *}$ & $0.17437^{* *}$ & $85.97^{* *}$ & $0.002669^{*}$ \\
C X RF & 21 & $2.70^{\text {n.s }}$ & $0.04017^{\text {n.s }}$ & $0.275^{\text {n.s }}$ & $0.067909^{\text {n.s }}$ & $0.0139^{*}$ & $0.01461^{* *}$ & $11.84^{* *}$ & $0.000623^{\text {n.s }}$ \\
CV $_{\text {exp }}(\%)$ & & 6.6 & 23.30 & 5.80 & 25.1 & 3.6 & 11.2 & 7.7 & 12.9 \\
\hline
\end{tabular}

** significant at $1 \%$; significant at $5 \%$; n.s - nonsignificant at $5 \% . \mathrm{Ln}=$ natural logarithm; $\mathrm{CV}_{\text {exp }} \%=$ coefficient of variation of untransformed variable. $\mathrm{H}=$ height. $\mathrm{R}=$ root dry matter. $\mathrm{PA}=$ shoot dry matter. $\mathrm{DC}=$ root collar diameter. IQD $=\mathrm{Dickson}$ quality index.
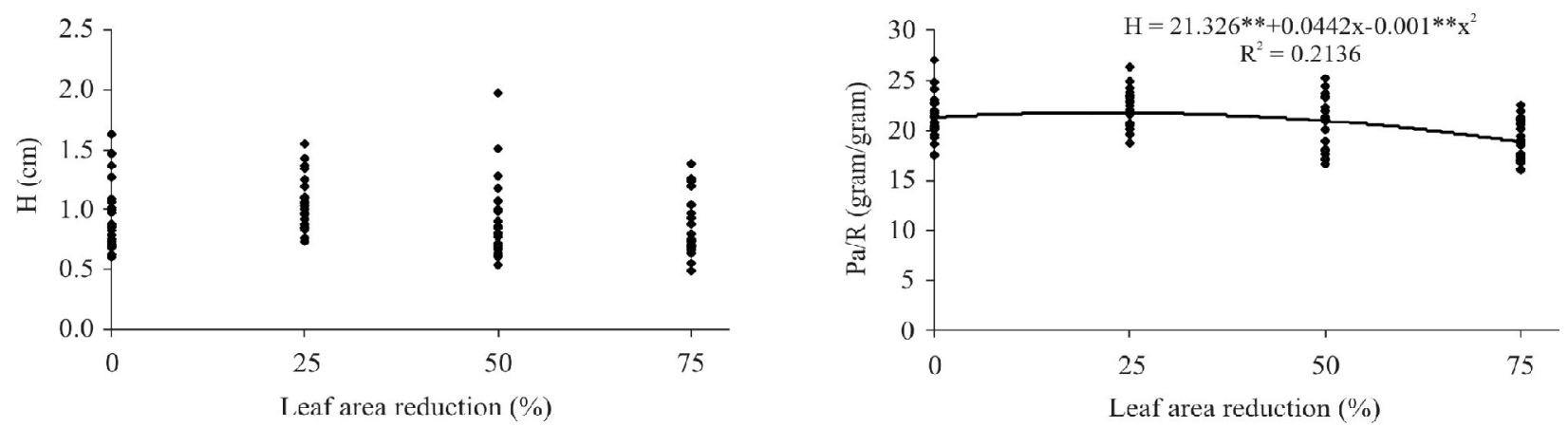

Figure 1 - Height $(H)$ and shoot/root $(P A / R)$ relationship of eucalyptus seedlings 105 days old according to different leaf reduction treatments.

Figura 1 - Relação parte aérea/raiz $(P A / R)$ e altura $(H)$ de mudas de eucalipto aos 105 dias de idade para os diferentes tratamentos de redução foliar. 
Table 2 shows that in $37.5 \%$ of cases the means of variables per clone are presented. In such cases there was no equation fit up to the $5 \%$ probability level. Therefore any of the presently evaluated leaf reduction levels can be adopted. In order to minimize labor and avoid repetitive work by nursery staff, the $0 \%$ leaf reduction level is the most recommended.

Root collar diameter and height are easily measured, nondestructive variables, and for these reasons they are widely used by nurseries engaged in seedling production of forest species (CARNEIRO 1995). As regards DC, in all fittings using simple linear regression the $b_{1}$ coefficient has a negative sign, which demonstrates the negative effect of leaf reduction. This effect is observed in $50 \%$ of clones and, in clones where a quadratic fit was observed, the maximum estimated value was $2.54,2.34,2.32$ and 2.46 for clones $2,3,4$ and 5 respectively (Table 2 ).

It was also noted that, when using the $0 \%$ leaf reduction level, the growth of root collar diameter lay within the $2.21 \mathrm{~mm}$ to $2.56 \mathrm{~mm}$ range (Table 2). According to Carneiro (1995), a root collar diameter above $2 \mathrm{~mm}$ is the suitable lower bound for transferring E. urophylla seedlings to the field and, as such, all clones are expected to develop well in the field irrespective of the leaf reduction level being used.

The $H / P A$ relationship can be of great importance to estimate the seedling survival potential in the field. Higher values of $H / P A$ indicate increasingly less leaf matter for the same reference height, which may indicate less water demand by seedlings, a desirable situation at the field level. These results agree with results obtained by Gomes et al. (2002).

As for $P A$ and $I Q D$, a predominance was observed of negative simple linear fit and a nonsignificant equation for most clones (Table 2). It is therefore recommended that a $0 \%$ level of leaf reduction be adopted, as it allows a similar development to other levels, it does not cause stress to stem minicuttings as a result of leaf reduction, it reduces the risk of fungus contamination by preventing leaf injury, but first and foremost it minimizes labor and risk of disease by repetitive effort in the nursery. These results agree with results obtained by Santana et al. (2007) after studying the effect of leaf area reduction on nine eucalyptus clones.

All quadratic fits being considered, the variation of maximum growth point for different variables ranged from $22.1 \%$ to $34.8 \%$, with an average $27.4 \%$ leaf reduction (Table 2 ). These values are below the $50 \%$ leaf reduction percentage widely used in clonal eucalyptus nurseries in Brazil (XAVIER et al. 2009), yet they agree with recommendations by Alfenas et al. (2004).

Cerne, Lavras, v. 16, n. 3, p. 251-257, jul./set. 2010
The quality of a plant's root system is reflected directly on its field survival, particularly when the season is unfavorable for plant development (MAFIA et al. 2005). These authors concluded that root dry matter is an important variable with which to define the age when seedlings are ready for planting, and also that approximately $0.55 \mathrm{~g}$ of root per plant is the suitable weight to transfer seedlings to the field. Table 3 illustrates that all clones presented higher values than those established by Mafia et al. (2005).

The $H / D C$ relationship indicates growth equilibrium, relating these two morphological parameters in a single index, with 7.5 being the minimum bound considered suitable for seedlings to be planted (CARNEIRO 1995). All clones presented higher values than the above minimum bound (Table 3 ).

An analysis of Table 3 shows that, overall, differences among clones are of low magnitude for all variables, which is expected, since all evaluated clones are commercially grown materials and are simultaneously produced on an operational scale.

As the experiment progressed, no incidence of pathogens was observed, nor reduced irrigation efficiency due to the umbrella effect, nor excess transpiration leading to minicutting bending. The occurrence of these problems is the main argument to justify leaf reduction since the days of seedling production by macrocutting. A $0 \%$ leaf reduction is believed to have become viable because of the improved efficiency of irrigation systems in recent years and because, being younger and thus having less leaf area in comparison to macrocuttings, apical minicuttings are used instead.

Another very important variable to consider is seedling survival, as it defines better economic viability in nurseries. Results of this variable did not meet normality assumptions, as illustrated in Figure 2. Different behaviors are observed among clones regarding each leaf reduction level. Clones 2, 7 and 8 showed higher mortality with no leaf reduction. This effect was more pronounced in clones 7 and 8 , as the survival rate of around $80 \%$ with no leaf reduction is well below other treatments. With the other five clones, on the other hand, a $0 \%$ leaf reduction can be adopted. According to Hartmann et al. (2002), for many species the presence of leaves or a portion of them is a precondition for production of auxins and rooting cofactors that are translocated to the minicutting base, favoring rhizogenesis. Supporting observations here, the above authors argue that different genetic materials can show different responses as a function of the presence of leaves or a portion of them. 
Table 2 - Coefficients of regression equations for different variables (y) as a function of leaf reduction level (x), for clonal eucalyptus seedlings 105 days old.

Tabela 2 - Coeficientes das equações de regressão obtidos para as diferentes variáveis (y) analisadas em função do nível de redução foliar $(x)$ para mudas clonais de eucalipto com 105 dias de idade.

\begin{tabular}{|c|c|c|c|c|}
\hline \multirow{2}{*}{ Clone } & \multicolumn{3}{|c|}{ Coefficients } & \multirow{2}{*}{$\mathrm{R}^{2}$} \\
\hline & $\mathrm{b}_{0}$ & $\mathrm{~b}_{1}$ & $\mathrm{~b}_{2}$ & \\
\hline & \multicolumn{4}{|c|}{$\mathrm{PA}$} \\
\hline $\mathrm{C} 1$ & $0.614^{* *}$ & $-0.001850^{* *}$ & --- & 0.5767 \\
\hline $\mathrm{C} 2$ & $0.766^{* *}$ & $0.008113^{*}$ & $-0.000142^{* *}$ & 0.7298 \\
\hline $\mathrm{C} 3$ & $0.783^{* *}$ & $-0.002282^{*}$ & --- & 0.4337 \\
\hline $\mathrm{C} 4$ & \multicolumn{4}{|c|}{$\hat{y}=\bar{y}=0.63$} \\
\hline $\mathrm{C} 5$ & $0.667^{* *}$ & $0.011120^{* * *}$ & $-0.000164^{* *}$ & 0.6773 \\
\hline C6 & \multicolumn{4}{|c|}{$\hat{y}=\bar{y}=0.711$} \\
\hline $\mathrm{C} 7$ & \multicolumn{4}{|c|}{$\hat{y}=\bar{y}=0.766$} \\
\hline $\mathrm{C} 8$ & $0.872^{* *}$ & $-0.003007^{* *}$ & --- & 0.5138 \\
\hline & \multicolumn{4}{|c|}{$\mathrm{H} / \mathrm{PA}$} \\
\hline $\mathrm{C} 1$ & $30.07^{* *}$ & $0.06862^{*}$ & --- & 0.4499 \\
\hline $\mathrm{C} 2$ & $28.20^{* * *}$ & $-0.08828^{\mathrm{ns}}$ & $0.00194^{*}$ & 0.6385 \\
\hline $\mathrm{C} 3$ & \multicolumn{4}{|c|}{$\hat{y}=\bar{y}=26.19$} \\
\hline $\mathrm{C} 4$ & $30.58^{* *}$ & $-0.13663^{\mathrm{ns}}$ & $0.00294^{*}$ & 0.6111 \\
\hline $\mathrm{C} 5$ & $30.85^{* *}$ & $-0.31241^{*}$ & $0.00449^{* * *}$ & 0.6502 \\
\hline C6 & \multicolumn{4}{|c|}{$\hat{y}=\bar{y}=29.67$} \\
\hline $\mathrm{C} 7$ & \multicolumn{4}{|c|}{$\hat{y}=\bar{y}=30.16$} \\
\hline $\mathrm{C} 8$ & \multicolumn{4}{|c|}{$\hat{y}=\bar{y}=30.61$} \\
\hline & \multicolumn{4}{|c|}{$\mathrm{DC}$} \\
\hline $\mathrm{C} 1$ & $2.21^{* *}$ & $-0.002225^{*}$ & --- & 0.3546 \\
\hline $\mathrm{C} 2$ & $2.45^{* *}$ & $0.007896^{\mathrm{ns}}$ & $-0.000157^{*}$ & 0.6447 \\
\hline $\mathrm{C} 3$ & $2.27^{* *}$ & $0.004983^{\mathrm{ns}}$ & $-0.000095^{*}$ & 0.6097 \\
\hline $\mathrm{C} 4$ & $2.26^{* * *}$ & $0.005154^{\mathrm{ns}}$ & $-0.000107^{*}$ & 0.5893 \\
\hline $\mathrm{C} 5$ & $2.32^{* *}$ & $0.009835^{*}$ & $-0.000173^{* *}$ & 0.6625 \\
\hline C6 & $2.32^{* *}$ & $-0.003131^{* *}$ & --- & 0.5078 \\
\hline $\mathrm{C} 7$ & $2.55^{* *}$ & $-0.002111^{*}$ & --- & 0.3481 \\
\hline \multirow[t]{2}{*}{$\mathrm{C} 8$} & $2.56^{* *}$ & $-0.003878^{* *}$ & --- & 0.6866 \\
\hline & \multicolumn{4}{|c|}{ IQD } \\
\hline $\mathrm{C} 1$ & $0.1321^{* *}$ & $-0.000340^{* *}$ & --- & 0.5301 \\
\hline $\mathrm{C} 2$ & $0.1745^{* *}$ & $-0.000602^{*}$ & --- & 0.4340 \\
\hline $\mathrm{C} 3$ & \multicolumn{4}{|c|}{$\hat{y}=\bar{y}=0.17428$} \\
\hline $\mathrm{C} 4$ & $0.1182^{* *}$ & $0.001346^{\circ}$ & $-0.000021^{*}$ & 0.4998 \\
\hline $\mathrm{C} 5$ & \multicolumn{4}{|c|}{$\hat{y}=\bar{y}=0.14956$} \\
\hline C6 & \multicolumn{4}{|c|}{$\hat{y}=\bar{y}=0.13374$} \\
\hline $\mathrm{C} 7$ & \multicolumn{4}{|c|}{$\hat{y}=\bar{y}=0.16464$} \\
\hline $\mathrm{C} 8$ & \multicolumn{4}{|c|}{$\hat{y}=\bar{y}=0.15611$} \\
\hline
\end{tabular}

Cerne, Lavras, v. 16, n. 3, p. 251-257, jul./set. 2010 
Table 3 - Means of variables evaluated in seedlings of eight eucalyptus clones 105 days old.

Tabela 3 - Médias das variáveis avaliadas nas mudas de oito clones de eucalipto aos 105 dias de idade.

\begin{tabular}{|c|c|c|c|c|c|c|c|c|c|c|c|c|c|c|c|c|c|}
\hline \multirow{2}{*}{ Clone } & \multicolumn{17}{|c|}{ Variables } \\
\hline & $\mathrm{H}$ & & & & $\mathrm{R}$ & & & & H/DC & & & $\mathrm{PA} / \mathrm{R}$ & & & & & \\
\hline $\mathrm{C} 1$ & 19.2 & & & c $\quad$ d & 0.69 & & $\mathrm{~b}$ & $\mathrm{c}$ & 9.06 & $a b$ & & 0.80 & & $\mathrm{~b}$ & c & & \\
\hline $\mathrm{C} 2$ & 21.8 & $\mathrm{a}$ & $\mathrm{b}$ & & 0.78 & $\mathrm{a}$ & $\mathrm{b}$ & $\mathrm{c}$ & 9.09 & $\mathrm{a} \quad \mathrm{b}$ & & 1.02 & $\mathrm{a}$ & $\mathrm{b}$ & c & & \\
\hline $\mathrm{C} 3$ & 18.1 & & & $\mathrm{~d}$ & 0.95 & $\mathrm{a}$ & & & 8.03 & & $\mathrm{c}$ & 0.79 & & & c & & \\
\hline $\mathrm{C} 4$ & 19.5 & & & c d & 0.56 & & & $\mathrm{c}$ & 8.78 & $\mathrm{~b}$ & & 1.15 & $\mathrm{a}$ & & & & \\
\hline $\mathrm{C} 5$ & 20.6 & & $\mathrm{~b}$ & $\mathrm{c}$ & 0.76 & $\mathrm{a}$ & $\mathrm{b}$ & c & 8.92 & $\mathrm{a} \quad \mathrm{b}$ & & 0.98 & $\mathrm{a}$ & $\mathrm{b}$ & c & & \\
\hline C6 & 20.8 & & $\mathrm{~b}$ & $\mathrm{c}$ & 0.68 & & $\mathrm{~b}$ & $\mathrm{c}$ & 9.45 & $\mathrm{a}$ & & 1.10 & $\mathrm{a}$ & $\mathrm{b}$ & & & \\
\hline $\mathrm{C} 7$ & 23.0 & $\mathrm{a}$ & & & 0.98 & $\mathrm{a}$ & & & 9.33 & $\mathrm{a} \quad \mathrm{b}$ & & 0.80 & & $\mathrm{~b}$ & c & & \\
\hline $\mathrm{C} 8$ & 22.9 & $\mathrm{a}$ & & & 0.91 & $\mathrm{a}$ & $\mathrm{b}$ & & 9.49 & $\mathrm{a}$ & & 0.91 & $\mathrm{a}$ & $\mathrm{b}$ & c & & \\
\hline \multirow[t]{2}{*}{ Mean } & 20.7 & & & & 0.79 & & & & 9.02 & & & 0.94 & & & & & \\
\hline & DC & & & & PA & & & & $\mathrm{H} / \mathrm{PA}$ & & & IQD & & & & & \\
\hline $\mathrm{C} 1$ & 2.1 & & & $\mathrm{~d}$ & 0.54 & & & $\mathrm{c}$ & 35.6 & $\mathrm{a}$ & & 0.13 & & & & $\mathrm{~d}$ & $\mathrm{e}$ \\
\hline $\mathrm{C} 2$ & 2.4 & $\mathrm{a}$ & $\mathrm{b}$ & & 0.76 & $\mathrm{a}$ & & & 29.1 & $\mathrm{~b}$ & $\mathrm{c}$ & 0.15 & & $\mathrm{~b}$ & c & $\mathrm{d}$ & \\
\hline $\mathrm{C} 3$ & 2.3 & & & $\mathrm{c}$ & 0.70 & $\mathrm{a}$ & $\mathrm{b}$ & & 26.2 & & $\mathrm{c}$ & 0.19 & $\mathrm{a}$ & & & & \\
\hline $\mathrm{C} 4$ & 2.2 & & & c d & 0.63 & & $\mathrm{~b}$ & $\mathrm{c}$ & 31.9 & $\mathrm{~b}$ & & 0.12 & & & & & $\mathrm{e}$ \\
\hline $\mathrm{C} 5$ & 2.3 & & $\mathrm{~b}$ & $\mathrm{c}$ & 0.73 & $\mathrm{a}$ & $\mathrm{b}$ & & 29.0 & $\mathrm{~b}$ & $\mathrm{c}$ & 0.15 & & $\mathrm{~b}$ & & $\mathrm{~d}$ & \\
\hline C6 & 2.2 & & & c d & 0.71 & $\mathrm{a}$ & $\mathrm{b}$ & & 29.7 & $\mathrm{~b}$ & & 0.13 & & & & $\mathrm{~d}$ & e \\
\hline C7 & 2.5 & $\mathrm{a}$ & & & 0.77 & $\mathrm{a}$ & & & 30.2 & $\mathrm{~b}$ & & 0.17 & $\mathrm{a}$ & $\mathrm{b}$ & & & \\
\hline $\mathrm{C} 8$ & 2.4 & $\mathrm{a}$ & & & 0.76 & $\mathrm{a}$ & & & 30.6 & $\mathrm{~b}$ & & 0.16 & $\mathrm{a}$ & $\mathrm{b}$ & c & & \\
\hline Mean & 2.3 & & & & 0.70 & & & & 30.2 & & & 0.15 & & & & & \\
\hline
\end{tabular}

Means followed by the same letter in the column do not differ statistically by the Tukey test at the 5\% probability level. $\mathrm{H}-$ height (cm); R - root dry matter (g/plant); PA - shoot dry matter (g/plant); DC - root collar diameter (mm); IQD - Dickson quality index; Ln - natural logarithm.

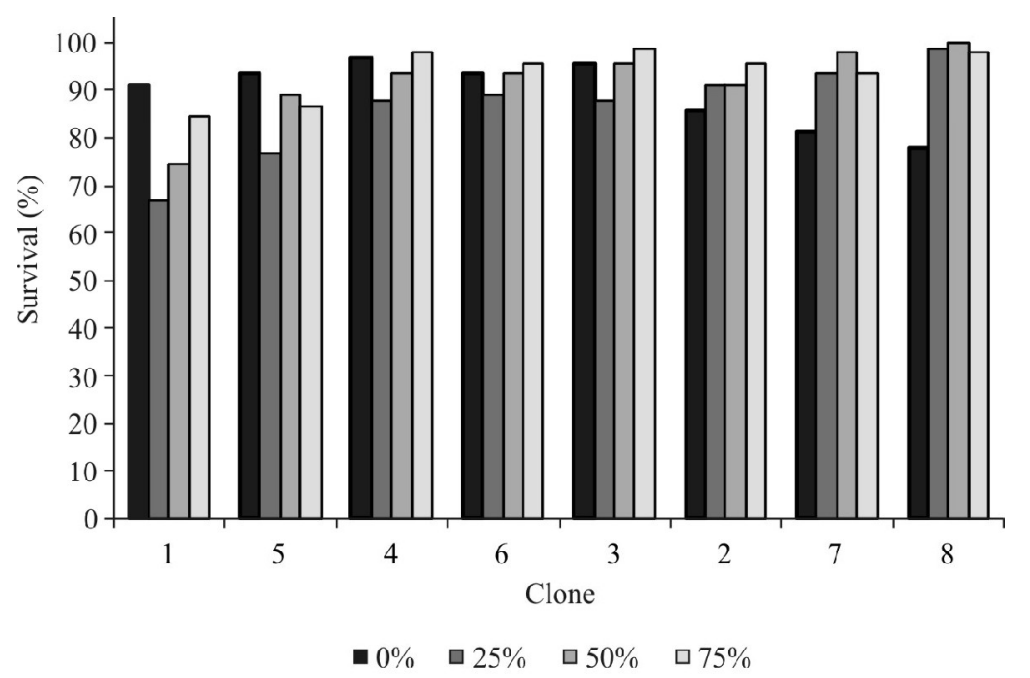

Figure 2 - Average survival of eucalyptus clones 105 days old, for different leaf reduction treatments.

Figura 2 - Sobrevivência média dos clones de eucalipto aos 105 dias de idade para os diferentes tratamentos de redução foliar.

Cerne, Lavras, v. 16, n. 3, p. 251-257, jul./set. 2010 


\section{CONCLUSIONS} reduction.

Genetic materials behaved differently to leaf

The $0 \%$ leaf reduction level is a viable alternative for most clones in question, in order to produce eucalyptus seedlings from apical minicuttings.

\section{ACKNOWLEDGMENTS}

We wish to thank Plantar Reflorestamentos S.A. for providing the genetic material (clones), financial support, staff and infrastructure.

We also wish to thank FAPEMIG for granting the Scientific Initiation scholarship.

\section{BIBLIOGRAPHICAL REFERENCES}

ALFENAS, A. C.; ZAUZA, E. A. V.; MAFIA, R. G.; ASSIS, T. F. Clonagem e doenças do eucalipto. Viçosa, MG: UFV, 2004. 442 p.

ÁlvareS, V. V. H.; ÁllareS, G. A. M. Apresentação de equações de regressão e suas interpretações. Boletim Informativo da Sociedade Brasileira de Ciência do Solo, Campinas, v. 28, n. 3, set./dez. 2003.

BELLAMINE, J.; PENEL, C.; GREPPIN, H.; GASPAR, T. Confirmation of the role of auxin and calcium in the late phases of adventitious root formation. Plant Growth Regulation, v. 26, p. 191-194, 1998.

CARNEIRO, J. G. A. Produção e controle de qualidade de mudas florestais. Curitiba: UFPR, 1995. 451 p.

FOGAÇA, C.M.; FETT-NETO, A. G. Role of auxin and its modulators in the adventitious rooting of Euclyptus species differing in recalcitrance. Plant Growth Regulation, v. 45, p. 1-10, 2005.

GOMES, J. M.; COUTO, L.; LEITE, H. G.; XAVIER, A.; GARCIA, S. L. R. Parâmetros morfológicos na avaliação da qualidade de mudas de Eucalyptus grandis. Revista Árvore, Viçosa, v. 26, n. 6, p. 655-664, 2002.

HARTMANN, H. T.; KESTER, D. E.; DAVIS JÚNIOR, F. T.; GENEVE, R. L. Plant propagation: principles and practices. 7. ed. New York: Englewood Clipps, 2002. 880 p.

HIGASHI, E. N.; SILVEIRA, R. L. A.; GONÇALVES, A. N. Evolução do jardim clonal de eucalipto para produção de mudas. IPEF, Piracicaba, v. 24, p. 148, 2000.
MAFIA, R. G.; ALFENAS, A. C.; SIQUEIRA, L.; FERREIRA, E. M.; LEITE, H. G.; CAVALLAZZI, J. R. P. Critério técnico para determinação da idade ótima de mudas de eucalipto para plantio. Revista Árvore, Viçosa, v. 29, p. 947 953, 2005.

NOBERTO, P. M.; CHALFUN, N. N. J.; PASQUAL, M.; VEIGA, R. D.; PEREIRA, G. E.; MOTA, J. H. Efeito da época de estaquia e do AIB no enraizamento de estacas de figueira (Fícuscarica L.). Ciência e Agrotecnologia, Lavras, v. 25, n. 3, p. 533-541, 2001.

SANTANA, R. C.; DIAS, B. A. S.; DUTRA, T. R.; NOGUEIRA, G. S.; OLIVEIRA, M. N. S.; SOUZA, C. M. P.; SILVA, M. P.; GRAZZIOTTI, P. H. Influência da área foliar na produção de matéria seca de miniestacas de eucalipto. In: CONGRESSO BRASILEIRO DE CIÊNCIA DO SOLO, 31., 2007, Gramado. Anais... Gramado: Sociedade Brasileira de Ciência do Solo, 2007. CD-ROM.

SCHAWAMBACH, J.; FADANELLI, C.; FETT-NETO, A. G. Mineral nutrition and adventitious rooting in microcuttings of Eucalyptus globulus. Tree Physiology, Victoria, v. 25, p. 484494, 2005.

TITON, M.; XAVIER, A.; OTONI, W. C. Clonal propagation of Eucalyptus grandis using the mini-cutting and micro-cutting techinics. Scientia Forestalis, Piracicaba, n. 71, p. 109-117, 2006.

TITON, M.; XAVIER, A.; REIS, G. G.; OTONI, W. C. Eficiência das minicepas e microcepas na produção de propágulos de clones de Eucalyptus grandis. Revista Árvore, Viçosa, v. 27, n. 5, p. 619-625, 2003.

VALLE, C. F.; CALDEIRA, C. J. Fatores que afetam o enraizamento de estacas de Eucalyptus sp. IPEF, Piracicaba, v. 6, n. 18 , p. $107-117,1978$.

XAVIER, A.; WENDLING, I.; SILVA, R. L. Silvicultura clonal: princípios e técnicas. Viçosa, MG: UFV, 2009. 272 p.

WENDLING, I.; XAVIER, A. Influência do ácido indolbutírico e ds miniestaquia seriada no enraizamento e vigor de miniestacas de clones de Eucalyptus grandis. Revista Árvore, Viçosa, v. 29, n. 6, p. 921-930, 2005.

Cerne, Lavras, v. 16, n. 3, p. 251-257, jul./set. 2010 